\title{
A video demonstration of pacemaker-induced pectoral muscle stimulation
}

\author{
Ida Kirstine Bull Rasmussen, ${ }^{1}$ Manan Pareek ${ }^{2}$
}

${ }^{1}$ Faculty of Health Sciences, University of Southern Denmark, Odense C, Denmark ${ }^{2}$ Department of Cardiology, Aarhus University Hospital, Skejby, Aarhus N, Denmark

\section{Correspondence to}

Dr Manan Pareek mananpareek@dadlnet.dk
CrossMark

To cite: Bull Rasmussen IK, Pareek M. BMJ Case Rep Published online: [please include Day Month Year] doi:10.1136/bcr-2013200697

\section{DESCRIPTION}

An 82-year-old woman was admitted with symptoms presumed to be palpitations. The symptoms had been present intermittently for the past few weeks. The patient had a DDDR pacemaker on the left side, which was implanted 4 years earlier due to third degree atrioventricular block. Physical examination showed rhythmic contraction of the left pectoral muscle (see video 1). The contractions were synchronous with the paced rhythm as seen on a cardiac monitor. Furthermore, a few episodes of failure to capture were recorded. A high ventricular capture threshold above $3 \mathrm{~V}$ at $0.5 \mathrm{~ms}$ pulse width and reduced pacing impedance below $200 \Omega$ were found in the bipolar configuration. The threshold was normal in the unipolar configuration; however, the pectoral muscle contractions persisted. The patient was transferred to an invasive cardiac centre, where a new right ventricular pacing lead was placed. Immediately after implantation, the capture threshold was $0.75 \mathrm{~V}$ at $0.4 \mathrm{~ms}$ pulse width, and the impedance was $640 \Omega$ in the bipolar configuration. As expected, the old lead had an insulation defect just below the generator.

Pacemaker-induced extracardiac stimulation normally involves the diaphragm, the pectoral or the intercostal muscles. Common causes of local muscle contractions are insulation defect of the lead, positioning of the anode directly on the

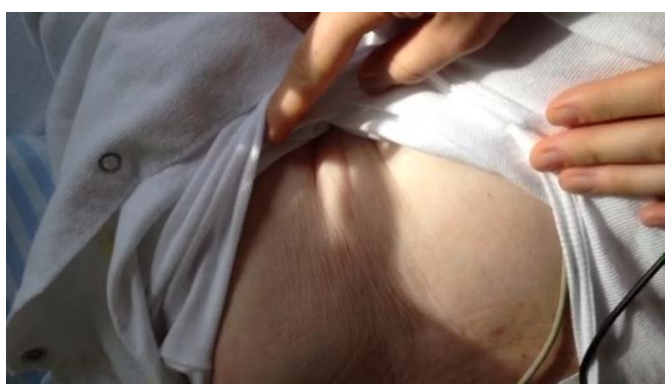

Video 1 Pacemaker-induced stimulation of the left pectoral muscle. muscle, defective coating of the pacemaker can or connector problems. ${ }^{12}$ In this case, lead insulation defect was suspected due to reduced pacing impedance. The diagnosis was supported by an increased capture threshold. Stimulation can be lessened by decreasing the output parameters, although an adequate safety margin must be maintained. Lead repositioning or replacement is required if the problem cannot be resolved by reprogramming. ${ }^{3}$

\section{Learning points}

Pacemaker-induced extracardiac stimulation normally involves the diaphragm, the pectoral or the intercostal muscles.

- Lead insulation defect is a common cause of local muscle contractions and should be suspected when the lead impedance is reduced.

- Lead repositioning or replacement is required if the problem cannot be resolved by reprogramming.

\section{Competing interests None.}

Patient consent Obtained.

Provenance and peer review Not commissioned; externally peer reviewed.

\section{REFERENCES}

1 Stroobandt R, Willems R, Depuydt P, et al. The superfast atrial recharge pulse: a cause of pectoral muscle stimulation in patients equipped with a unipolar DDD pacemaker. Pacing Clin Electrophysiol 1989;12:451-5.

2 Radcliffe PJ, Jones S, Ward DE. An unusual cause of pacemaker current leakage causing muscle stimulation. Pacing Clin Electrophysiol 1981;4:589-91.

3 Haghjoo M. Pacing system malfunction: evaluation and troubleshooting, modern pacemakers - present and future. Das MR, ed., InTech, 2011. http://www.intechopen.com/books/ modern-pacemakers-present-and-future/pacing-systemmalfunctionevaluation-and-troubleshooting ( Jul 2013) 
Copyright 2014 BMJ Publishing Group. All rights reserved. For permission to reuse any of this content visit http://group.bmj.com/group/rights-licensing/permissions.

BMJ Case Report Fellows may re-use this article for personal use and teaching without any further permission.

Become a Fellow of BMJ Case Reports today and you can:

- Submit as many cases as you like

- Enjoy fast sympathetic peer review and rapid publication of accepted articles

- Access all the published articles

- Re-use any of the published material for personal use and teaching without further permission

For information on Institutional Fellowships contact consortiasales@bmjgroup.com

Visit casereports.bmj.com for more articles like this and to become a Fellow 